ELORE (ISSN 1456-3010), vol. 20 - 2/2013.

Julkaisija: Suomen Kansantietouden Tutkijain Seura ry.

[http://www.elore.fi/arkisto/2_13/leppalahti.pdf]

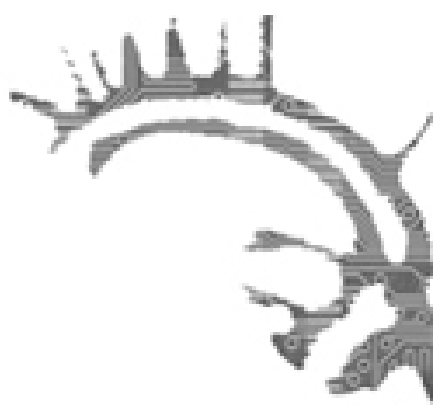

\title{
KIRJA-ARVIO
}

\section{PEIKKOJA, VARSÅGODA!}

\author{
Merja Leppälahti
}

HENRIKSSON, BLANKA 2012: Trollen och vi. Folkliga föreställningar i Svenskfinland. Vasa: Scriptum. 86 sivua.

Blanka Henriksson on tarkastellut suomenruotsalaisia mielikuvia peikoista uskomustarinoiden ja kansanuskomusten, satujen ja sanontojen valossa. Trollen och $v i$-teoksen aineisto on peräisin Varsinais-Suomen, Uudenmaan, Ahvenanmaan ja Pohjanmaan ruotsinkielisiltä alueilta. Aineisto on arkistoitu Svenska litteratursällskapetin arkistoon ja Åbo Akademin folkloristisiin kokoelmiin. Jonkin verran Henrikssonin käyttämää aineistoa on myös painettu 1900-luvun alkupuolelta lähtien, tärkeimpänä Finlands svenska folkdiktning -sarja.

Henriksson aloittaa kertomalla yliluonnollisia aineksia sisältävistä kansankertomuksista. Uskomustarina (sägen) on kertomus, joka kiinnittyy jollakin lailla kertojien ja kuulijoiden todellisuuteen. Sen päähenkilöt ovat tavallisia ihmisiä, joille vain on sattunut jotain tavallisesta poikkeavaa. Satu (saga) sen sijaan kertoo fantasiapitoisista tapahtumista satumaailmoissa, joissa voidaan tavata prinssejä ja prinsessoja. Uskomustarina voisi olla totta, kun taas satua ei ole tarkoitus ottaa todesta, mikä kerrotaan kuulijoille esimerkiksi konventionaalisen alun tai lopetuksen avulla.

Henriksson muistuttaa, ettei ole syytä olettaa, että tarinoiden kertojat olisivat ilman muuta uskoneet kertomansa tarinat todeksi. Huolimatta siitä, että tarinat sijoittuvat tavalliseen maailmaan ja päähenkilöt voivat olla tuttuja ihmisiä, kertojat ja kuulijat 
ovat voineet epäillä tarinoiden todenperäisyyttä. Yliluonnolliseen uskomisessa on menneisyydessäkin ollut aste-eroja varmasta uskosta täydelliseen kiistämiseen saakka. Tarina voi olla mielenkiintoinen ja kertomisen arvoinen, vaikka sen todenperäisyyteen ei täysin uskoisikaan.

\section{METSIEN IHMISIÄ}

Nykyihminen kuvittelee peikot ulkonäöltään selvästi ihmisistä erottuviksi. Nykyiset suomenruotsalaiset peikkomielikuvat ovat kuitenkin pitkälti peräisin peikkosatujen kuvituksesta, erityisesti John Bauerin 1900-luvun alussa piirtämistä suurista ja groteskeista, pitkänenäisistä ja karvaisista olennoista. Kansantarinoissa peikot eivät läheskään aina ole näin selvästi erilaisia kuin ihmiset. Monissa vanhoissa tarinoissa ihminen ei heti edes tiedä olevansa tekemisissä peikkojen kanssa. Tarinoiden peikot muistuttavat ihmistä, mutta eivät käyttäydy ja toimi kuten ihminen: metsässä nähdyillä peikoilla voi olla yllään hienot juhlavaatteet, joissa ihminen ei liikkuisi maastossa, tai naispuolinen peikko voi kammata metsässä hiuksiaan, mitä ihmisnainen ei tekisi julkisesti. Tarinoissa peikot elivät ihmisten läheisyydessä ihmisten tapaan, menivät naimisiin, saivat lapsia, hoitivat karjaa ja jäljittelivät monin tavoin ihmisten elämäntapoja. Ihmisten näkökulmasta niissä oli kuitenkin jotain poikkeavaa ja erikoista, mikä osoitti, ettei kysymyksessä voinut olla ihminen.

Tarinoiden peikot saattoivat olla myös vaarallisia. Ne saattoivat houkutella tai ryöstää ihmisiä mukaansa. Peikkojen asumuksissa näytti olevan ylellistä ja yltäkylläistä. Herkulliselta vaikuttava ruoka osoittautui kuitenkin vastenmieliseksi, jos luki ruokarukouksen ja näki, mitä todellisuudessa oli tarjolla. Usein ihmiset vapautuivat lopulta peikkojen vallasta, mutta kaikki eivät koskaan palanneet, ja toisinaan peikkojen luota pois päässeet eivät koskaan henkisesti selvinneet kokemastaan. Peikot veivät myös ihmisten karjaa, vaihtoivat lapsia ja eksyttivät ihmisiä tuttuunkin metsään.

Yleisten uskomusten mukaan yliluonnollisista olennoilta on voinut suojautua kristillisillä symboleilla ja toiminnalla. Myös suomenruotsalaiset peikot ovat välttäneet ristejä ja kirkonkellojen ääntä ja kadonneet, kun Jeesuksen tai Jumalan nimi on mainittu. Herran siunauksen tai yleensäkin rukouksen lukemisen on monissa tarinoissa kerrottu murtaneen peikkojen vallan. Eksynyttä saattoi rukoilemisen lisäksi auttaa jonkin vaatekappaleen kääntäminen nurinpäin.

\section{HYVÄÄ PERUSTIETOA}

Trollen och vi esittelee suomenruotsalaista peikkoperinnettä monelta suunnalta. On helppo huomata, että suomenruotsalaisessa traditiossa peikot esiintyvät monissa sellaisissa rooleissa, joissa suomenkielisissä tarinoissa kyseessä olisi joku muu uskomusolento, kuten metsän- tai vedenhaltia. Esimerkiksi ihmiseltä näyttävällä naisella sormien välissä nähdyt räpylät osoittavat hänet peikoksi. Satujen peikot voisivat usein olla yhtä hyvin jättiläisiä 
tai piruja. Kun peikot joissakin uskomustarinoissa ovat selvästi vaarallisia olentoja, joilta täytyy osata suojautua, saduissa ne ovat ilkeitä, mutta helposti narrattavia.

Arkistojen tarina-ainesten lisäksi Henriksson esittelee myös nykyajan peikkoainesta. Peikko esiintyy yllättävän monessa ruotsinkielisessä sanonnassa ja sananlaskussa; näitä sanontoja käytetään edelleen ja niitä on ruotsin kielessä selvästi enemmän kuin suomessa. Kirjassa sivutaan lyhyesti myös populaarikulttuurin peikkoja. Peikkojen kuvailun ja muutamien peikkotarinoiden lisäksi Henriksson tarjoaa jonkun verran perustietoa kertomusperinteen lajeista ja tutkimuksesta, muun muassa satujen luokittelusta. Hän esittelee myös joitakin omia ja muiden tutkijoiden tulkintoja peikkotarinoiden mahdollisista funktioista.

Kaiken kaikkiaan Blanka Henrikssonin Trollen och vi antaa eloisan kuvan suomenruotsalaisesta peikkoperinteestä. Kirja on selvästi suunnattu peikoista tai yleensä kansanperinteestä kiinnostuneelle "tavalliselle lukijalle" eikä tutkijakunnalle, mutta se on kuitenkin laadittu kaikin puolin hyvän tieteellisen käytännön mukaisesti. Kirjan lopusta löytyvät muun muassa tiedot aineiston keruupaikkakunnista sekä esitettyjen tarinoiden lähdetiedot. Kirja sopii siten hyvin folkloristillekin pieneksi tutustumispaketiksi suomenruotsalaiseen uskomusperinteeseen.

Filosofian lisensiaatti Merja Leppälahti on turkulainen folkloristi, tietokirjailija ja kriitikko. 